Diabetologia $7,445-448(1971)$

(c) by Springer-Verlag 1971

\title{
Studies on the Effect of Thyroxine on in vivo Insulin Secretion as Modified by Hypophysectomy***
}

\author{
A. Renauld, J.E.B. Pinto, R. C. Sverdutk and V.G. Foglia \\ with the technical assistance of M.G. Pacloted and L. Carrera Vescro. \\ Instituto de Fisiologia, Facultad de Medicina, Universidad de Buenos Aires, Paraguay 2155, $7^{\circ}$ piso, Buenos Aires, \\ Argentina
}

Received: May 6, 1971, accepted: September 13, 1971

Summary. Blood sugar and serum immunoreactive insulin (IRT) concentrations were measured in uninjected and thyroxine-injected hypophysectomized dogs as well as in untreated normal dogs. Thyroxine was used at the following two levels: 0.5 and $100 \gamma / \mathrm{kg}$ body wt./day, for 10 days. Serum IRI levels in the dog in the post-absorptive conditions were unaffected by both treatments. Mildly subnormal blood sugar levels were detected in the hypophysectomized dog in the post-absorptive condition and were fully corrected by thyroxine therapy (both levels). The rate of disappearance of glucose from the blood was normal in the hypophysectomized control dogs and was unaffected by thyroxine therapy. The moderate increase in the general mean of the blood sugar through. out the test found after hypophysectomy was corrected by thyroxine (low level); thyroxine therapy (high dose) not only failed to correct the increase but in fact induced a further increase. The typical slow, low and maintained insulin response to hyperglycaemia was found in the hy pophysectomized control dogs, and it remained unchanged despite the thyroxine treatment (both levels). We con. cluded that the presence of the pituitary gland is needed so that the thyroxine-induced inhibition of the insulin secretory response to hyperglycaemia in vivo may be exerted.

Etude de l'effet de la thyroxine sur la séerétion d'in. suline uin vivon, modifiée par l'ablation de l'hypohyse

Résumé. Nous avons étudié l'effet de l'hypophysecto. mie totale sur l'inhibition de la sécrétion de l'insuline "in vivo" par la thyroxine, au cours d'hyperglycémies pro. voquées, chez le chien normal, hypophysectomisé et hypophysectomisé injecté avec de la thyroxine 10.5 et $100 \gamma / \mathrm{kg} / \mathrm{j}$, pendant 10 jours). On a dosé la glyeémje et l'insulinémie de ces animaux, dans des conditions de base, à jeun, et après la perfusion rapide intraveineuse de glucose. On a trouvé que la glycémie de base diminue après l'hypophysectomie et qu'elle se normalise par le traitement thyroxinique. L'insulinémie de base moyenne normale, à jeun, ne subit pas de modifications à la suite des deux traitements. Pendant l'épreuve dynamique, la glycémie moyenne générale atteint un niveau plus élevé chez le chien hypophysectomisé que chez le chien normal. Tandis que la faible dose de thyroxine $(0.5 \mathrm{\gamma} / \mathrm{kg} / \mathrm{j})$ peut corriger cette altération, celle-ci ne se corrige pas par la forte dose $(100 \mathrm{\gamma} / \mathrm{kg} / \mathrm{j})$ qui la fait encore augmenter. Cependant, la constante $\mathrm{k}$ de Conard ne se modifie pas à la suite de l'hypophysectomie chez le chien normal et elle reste normale après le traitement thyroxinique. Au cours de l'épreuve dynamique, l'insulinémie s'élève beaucoup moins, et surtout, reste plus longtemps élevée chez le chien hypophysectomisé que chez le chien témoin normal. Le traitement thyroxinique $(0.5$ et $100 \gamma / \mathrm{kg} / \mathrm{j})$ n'a pass entrainé d'inhibition de la sécrétion de l'insuline chez le chien hypophysectomisé. En conclusion: après l'ablation totale de la glande pituitaire, la thyroxine semble avoir perdu son efficacité pour inhiber la sécrétion insulinique chez le chien.

Untersuchungen über die Thyroxinwirkung auf die ,in vivo" Sekretion von Insulin nach Hypophysektomie

Zusammenfassung. Es wurde die Wirkung der totalen Hypophysektomie auf die Hemmung der Insulinsekretion "in vivo" untersucht. Dabei wurden an hypophyselstomierten Hunden mit und ohne Thyroxin-Vorbehandlung sowie an normalon Tieren Blutzuckerwerte und Insulinkonzentrationen gemessen. Thyroxin wurde in folgenden Dosen verabreicht: 0,5 und $100 \mathrm{\gamma} / \mathrm{kg}$ Körpergewicht pro Tag über 10 Tage. In hypophysektomierten Hunden wurden geringfügig verminderte Blutzuckernüchternwerte gefunden, die mit einer Thyroxinbehandlung mit beiden Dosen vollständig korrigiert werden konnten. Die Serum. insulinkonzentrationen am nüchternen Hund zeigten nach beiden Behandlungen keine Veränderungen. Bei einem Belastungsversuch wurden bei hypophysektomierten Hunden höhere Blutzuckerwerte erreicht als bei norma. len Hunden. Während die kleine Thyroxindosis $0,5 \gamma / \mathrm{kg}$ diese Veränderung verhindern konnte, war die große Do* sis von $100 \% / \mathrm{kg}$ dazu nicht in der Lage. Sie bewirkte sogar einen weiteren Anstieg. Die Seruminsulinkonzentrationen stiegen bei den hypophysektomierten Hunden im Gegen. satz zu den normalen Kontrolltieren während der Bela. stung weniger an, aber blieben länger erhöht. Die Thy* roxinbehandlung (in der hohen und niedrigen Dosis) hat bei den hypophysektomierten Hunden keine Verminderung der Insulinsekretion bewirkt. Daraus wird die Sohlußfolgerung gezogen, daß Thyroxin nach vollständiger Hypophysektomie seine dämpfende Wirkung auf die Insulinsekretion verloren zu haben scheint.

Key words: Hypophysectomized dogs-thyroxine treat. ment-serum immuno reactive insulin-intravenous glucose tolerance test.
* This work was partially supported by Research Grant No, 2304-B from the "Consejo Nacional de Investigaciones Científicas y Técnicas" (Argentina).
* This paper was partially presented at the Meetings of the VII Congress Intern. Diabetes Fedn, Buenos Aires, Argentina, 23-8 August, 1970 . 


\section{Introduction}

The thyroid hormones are the only pituitarydependent hormones so far known to exert a moderating role on the insulin response to a glucose stimulus in vivo. That role was demonstrated by Andreani, Menzinger, Fallucca, Aliberti and Tamburrane (1968) in hyperthyroid patients and by Renauld, Pinto, Sverdlik and Foglia (1971a) in the experimental hyperthyroid condition in the dog. Since the actual concentration of insulin in the blood depends upon a balance between insulin secretion and its disappearance from the blood, we carried out experiments to study the second possibility as influenced by hyperthyroidism. We found that the insulin disappearance rate constant is normal in the severely hyperthyroid dog; the insulin space remained unaffected as well (Renauld, Pinto, Sverdlik and Foglia, $1971 \mathrm{~b}$ ). The first possibility would then appear to be most definitely involved, although its mechanism remains still unknown. An indirect mechanism of the thyroid hormone effect exerted in vivo through a sensitization of the pancreatic effectors to the inhibitory action of epinephrine on the insulin secretion was demonstrated by several investigators, and reviewed by Freychet, Rosselin, Assan and Tchobroutsky (1967). Nevertheless, recent experiments (Orsetti, Basseres and Macabies, 1970) would rather support the view of increased insulin response to hyperglycaemia during the mildly hyperthyroid condition, thereby leading to $\beta$ cell exhaustion and to a poor insulin response to the glucose stimulus as severity of hyperthyroidism increases.

In a group of experiments we studied the inhibitory effect of thyroxine on insulin secretion as modified by pituitary hormones. In the present paper we report the results obtained in experiments carried out to demonstrate the effect of hypophysectomy on the changes in the action of thyroxin in vivo upon the insulin response to a glucose stimulus.

\section{Material and Methods}

Sixteen mongrel dogs, body weight ranging from 11.9 to $23.5 \mathrm{~kg}$ were used. They were fed on dog chow pellets and bones, and water ad libitum. Eight dogs out of the total group (dogs No. 33, 35, 41, 47, 49, 53, 55 and 57 ) were totally hypophysectomized (transtemporal approach) $2-4$ months prior to experiments. The remaining 8 were kept as normal control dogs (No. 13, 34, 36, 40, 42, 50 b, 56 and 58).

During the experiments, the dogs were awake, fasting (18-22 $\mathrm{h}$ fast) and kept as calm as possible. Two blood samples were withdrawn by venipuncture; the dogs were immediately tested for intravenous glucose tolerance with simultaneous measurement of serum immunoreactive insulin (IRI). Each dog received a rapid intravenous infusion of glucose $(1 \mathrm{~g}$ per $\mathrm{kg}$ body wt., in $20 \%(\mathrm{w} / \mathrm{v})$ aqueous solution) and was bled $5,15,25,45,60$ and 90 min after infusion. Thyrox- ine replacement therapy was performed through chronic subcutaneous l-thyroxine ${ }^{1}$ administration at one of the following doses: 0.5 and $100 \gamma / \mathrm{kg}$ body wt./day, for 10 days in $2 \mathrm{ml}$ saline. One hour after regimen completion a new intravenous glucose tolerance test (i.v. GTT) with simultaneous measurement of serum IRI was performed (self-control design). Serum IRI concentrations were estimated according to the Morgan and Lazarow technique, as modified by Stuart Soeldner and Slone (1965). Serum was obtained by blood clotting at room temperature $(1-2 \mathrm{~h})$, followed by centrifugation (5 $\mathrm{min}, 2500 \mathrm{r}$.p.m.) and storage $\left(-15^{\circ} \mathrm{C}\right)$. The dog serum was diluted $1: 2$ and eventually $1: 4$ for insulin assay; ox insulin ${ }^{2}$ was employed as a standard. The following system was used for the assay: 1) undiluted rabbit anti (Guinea pig total serum); 2) Guinea pig anti (ox insulin) serum, $1: 2000$ dilution; 3) tracer: ${ }^{125} \mathrm{I}$-insulin. Reagents No. 1 and 2 were prepared in our laboratories; radioactive insulin was purchased at the Radiochemical Centre, Amersham, Bucks., England. The results of serum IRI measurements were expressed as microunits per milliliter serum. A previously fluorinated sample of the same blood was used for sugar determination (Nelson, 1944); the results were expressed as milligrams reducing substances per $100 \mathrm{ml}$ of blood.

The results of either fasting blood sugar or serum IRI determinations (fasting or during the i.v. GTT) were statistically analyzed for variance, randomizedblock design (Lison, 1958); general mean of the blood sugar after glucose injection and Conard's $k$ constant per group (Conard, 1955) were calculated according to Bancroft (1960) and further analyzed (Student $t$-test).

\section{Results}

The results of measurements of fasting blood sugar are shown in table 1. The typical significant decrease in the levels of fasting blood sugar was found in hypophysectomized dogs prior to thyroxine therapy. The therapy $(0.5$ and $100 \gamma / \mathrm{kg}$ body wt.) enhanced the blood sugar values $(P<0.05$ and $P<0.01$ compared. with uninjected hypophysectomized dogs), the normal levels being achieved. The fasting serum IRI concentration was found to be unaffected by hypophysectomy either followed by thyroxine replacement therapy (both doses) or not.

Fig. 1 shows the results of serum IRI and blood sugar assay during the i.v. GTT in normal, hypophysectomized and thyroxine-injected $(0.5 \mathrm{\gamma} / \mathrm{kg}$ body wt.) hypophysectomized dogs. The constants for glucose disappearance from blood in the same animals

1 Synthetic l-thyroxine (sodium salt) provided by Glaxo Laboratories (Argentina); it was dissolved with the help of some drops of $\mathrm{N} \mathrm{NaOH}$ and further diluted with saline.

2 Crystalline glucagon-free insulin, potency 27. 5 I.U./ mg protein, provided by Hoechst Laboratories (Argentina), through the kindness of Dr. H. Schneider. 
(k) are shown in table 1. A mildly overnormal blood sugar curve was found after hypophysectomy $(P<$ 0.01); however, glucose disappeared from blood at a normal rate. Thyroxine therapy corrected the increased blood sugar levels throughout the test with no change in $k$ glucose thereby suggesting the possibility of a rising effect on the glueose space rather than on glucose utilization. response to hyperglycaemia was detected just $15 \mathrm{~min}$ after glucose infusion $(57 \mu \mathrm{U} / \mathrm{ml}, P<0.05)$; the maximum was achieved just 25 min after glucose load $(63 \mu \mathrm{U} / \mathrm{ml})$. In thyroxine-injected hypophysectomized dogs, the increase in serum IRI levels was found 25 min after infusion $(P<0.05)$, rapidly returning to base line. The thyroxine therapy failed to induce any change in the low and slow insulin response to intra-

Table 1. Fasting serum IRI and blood sugar levels and Oonard's $K$ constant in the hypophysectomized dog as modifid by thyroxine therapy. The figures in the table mean average $+S . E . ; N$ : number of cases; columns No. 1 and 2 belong to postabsorptive condition

\begin{tabular}{|c|c|c|c|c|c|c|c|c|}
\hline Dog. No. & Condition & $\begin{array}{l}\text { Dose of thyroxine } \\
\gamma / \mathrm{kg} \text { body wt./day } \\
\text { for } 10 \text { days }\end{array}$ & $\mathrm{N}$ & Serum 1 & $\mathrm{RI} \mu \mathrm{U} / \mathrm{ml}$ & $\begin{array}{l}\text { Blood s } \\
\mathrm{mg} / 100\end{array}$ & $\begin{array}{l}\text { gar } \\
\text { ml }\end{array}$ & $k$ \\
\hline $\begin{array}{l}34-36-40-42-50 b \\
33-35-41-47-49 \\
33-35-41-47-49\end{array}$ & $\begin{array}{l}\text { Normal } \\
\text { Hypox. } \\
\text { Bypox. }\end{array}$ & $\begin{array}{l}0 \\
0 \\
0.05\end{array}$ & $\begin{array}{l}5 \\
5 \\
5\end{array}$ & $\begin{array}{l}10 \pm 4 \\
15 \pm 8 \\
28 \pm 10\end{array}$ & $\begin{array}{l}28 \pm 11 \\
14 \pm 9 \\
18 \pm 12\end{array}$ & $\begin{array}{l}70 \pm 5 \\
63 \pm 3^{a} \\
76 \pm 6\end{array}$ & $\begin{array}{l}71+4 \\
59 \pm 20 \\
71+4\end{array}$ & $\begin{array}{l}0.0138 \\
0.0114 \\
0.0188\end{array}$ \\
\hline $\begin{array}{l}13-56-58 \\
53-55-57 \\
53-55-57\end{array}$ & $\begin{array}{l}\text { Normal } \\
\text { Hypox. } \\
\text { Hypox. }\end{array}$ & $\begin{array}{l}0 \\
0 \\
100\end{array}$ & $\begin{array}{l}3 \\
3 \\
3\end{array}$ & $\begin{array}{l}24 \pm 7 \\
25 \pm 14 \\
24 \pm 10\end{array}$ & $\begin{array}{r}17 \pm 9 \\
17 \pm 3 \\
9 \pm 8\end{array}$ & $\begin{array}{l}76 \pm 3 \\
53 \pm 3^{a} \\
61 \pm 5\end{array}$ & $\begin{array}{l}72 \pm 9 \\
46 \pm 9 \mathrm{a} \\
68 \pm 3\end{array}$ & $\begin{array}{l}0.0156 \\
0.0145 \\
0.0094\end{array}$ \\
\hline
\end{tabular}

a $P<0.02$ compared with nomal control dogs; all the other comparisons are not significant.
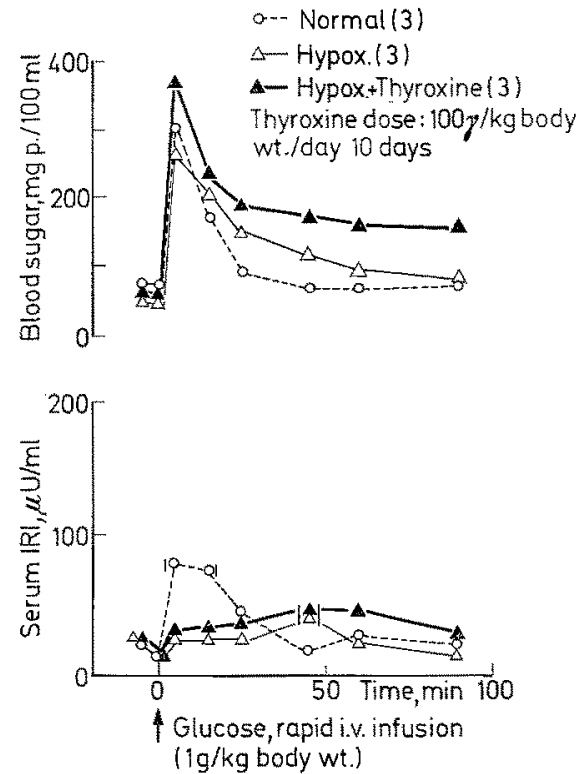

Fig. 1. Effect of the thyroxine replacement therapy on serum IRI and blood sugar levels in the hypophysectomized dog during the i.v. GTT. Thyroxine dose: $0.5 \gamma / \mathrm{kg}$ body wt./day, for 10 days. In parenthesis, number of animals per group

The insulin response to hyperglycaemia was typical in both normal and hypophysectomized control groups (see the bottom half of figure 1). In normal dogs, a five-fold increase in serum IRI levels above post-absorptive values was detected 5 min after glucose infusion $(105 \mu \mathrm{U} / \mathrm{ml}, P<0.001)$. They were still higher than base line $(P<0.01) 10$ minutes later. In uninjected hypophysectomized dogs, the insulin venously-induced hyperglycaemia in the hypophysectomized dog, whatever point of the serum IRI curve after glucose load is being considered $(P>0.05)$.

The results of serum IRI and blood sugar assays during the i.v. GTT in normal, hypophysectomized dogs and in thyroxine-injected $(100 \mathrm{\gamma} / \mathrm{kg}$ body wt.), hypophysectomized dogs are shown in figure 2. The constants for glucose disappearance from the blood in the same animals $(k)$ are shown in table 1 . The average blood sugar after glucose i.v. injection was hardly overnormal in this group of hypophysectomized dogs.
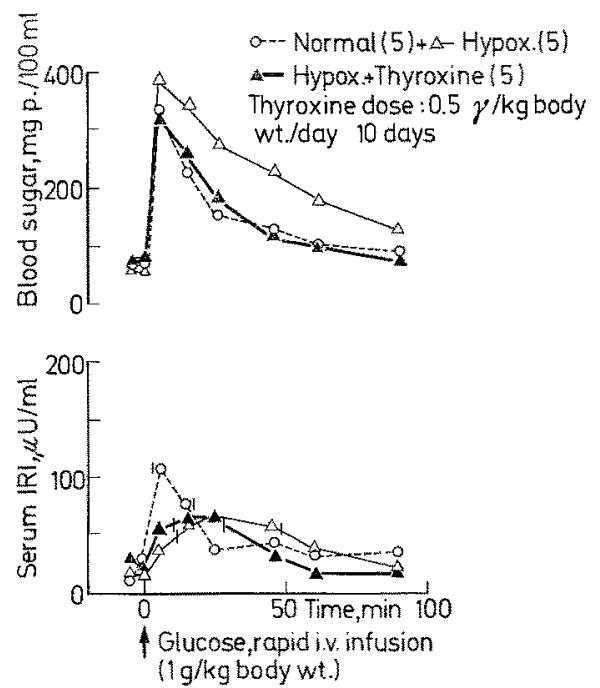

Fig. 2. Effect of the thyroxine replacement therapy on serum IRI and blood sugar levels in the hypophysectomized dog during the i.v. GTT. Thyroxine dose: $100 \mathrm{r} / \mathrm{kg}$ body wt./day, for 10 days. In parenthesis, number of animals per group 
Thyroxine, at this level, was not only unable to correct it, but rather induced a further increase $(P<$ 0.01 compared with the normal control dogs). It would appear then that thyroxine therapy at a high level reduces the glucose space in the hypophysectomized dog. $k$ glucose was normal in untreated hypophysectomized dogs and was unaffected by thyroxine therapy.

As shown in the bottom half of figure 2, the typical serum IRI curve during an i.v. GTT was found in the normal control group: 5 minutes after glucose infusion, serum IRI rose four-fold (to $81 \mu \mathrm{U} / \mathrm{ml}$ ) over post-absorptive values $(P<0.01) ; 25$ minutes after glucose load, the serum IRI was still above postabsorptive levels, only this difference was not significant. In the uninjected hypophysectomized group, the insulin response to hyperglycaemia was low and slow; it achieved its maximum just 45 minutes after glucose infusion $(42 \mu \mathrm{U} / \mathrm{ml})$ and immediately returned to post-absorptive levels. The thyroxine therapy (high dose) also failed to induce any significant change in the insulin response to the glucose stimulus, whatever point of the serum IRI curve after glucose load is being considered $(P>0.05)$.

\section{Discussion}

The results reported here demonstrate that the presence of the pituitary gland is needed so that thyroxine may induce a decrease in the insulin response to a glucose stimulus. Our results confirm previous reports about the low anti-insulinic effect of the thyroid hormones themselves. The combined treatment of thyroid feeding and injection of anterior pituitary extract induce the development of a diabetic condition in the normal dog, which is not observed after chronic administration of just thyroid gland (Houssay, 1945a). Furthermore: a previous treatment with anterior pituitary extracts sensitizes the pancreas to the diabetogenic action of the thyroid feeding in the partially depancreatized dog (Houssay, 1945 b).

In our experiments, the rate of disappearance of glucose from the blood after glucose load was unaffected by thyroxine therapy in the hypophysectomized dog. Since the serum IRI levels also remained unchanged after therapy, we may then conclude that the typical higher-than-normal insulin sensitivity to endogenous insulin in the hypophysectomized dog failed to be changed by chronic thyroxine therapy. This is in elose agreement with the results of experiments carried out by several investigators (Soskin, Levine and Heller, 1939; De Bodo and Sinkoff, 1953; De Bodo and Altszuler, 1958) who reported that the thyroid hormone treatment is unable to correct the hypersensitivity to exogenous insulin in the hypophysectomized dog.

Soskin, Levine and Heller (1939) found that thyroxine therapy corrects the tendency to hypoglycaemic crisis in the hypophysectomized dog during starvation, through a relatively greater increase in the rate of formation than in the rate of utilization of blood sugar. The enhancement of the fasting $(18-22 \mathrm{~h}$ fast) blood sugar levels in the hypophysectomized dog following thyroxine therapy that we are reporting here confirms their findings.

Our results reported in the present paper, led us to conclude that the thyroxine-inhibitory action on the insulin response in vivo to hyperglycaemia, disappears after hypophysectomy in the dog, thus suggesting a significant interaction between thyroxine and hypophyseal hormones on the regulation of insulin secretion.

\section{References}

Andreani, D., Menzinger, G., Fallucca, F., Aliberti, A., Tamburrane, G.: Carbohydrate metabolism and blood insulin in myxoedema. Diabetologia 4, 375-375 (1968).

Baneroft, H.: Introducción a la bioestadística, p. 193 .

Buenos Aires: Editorial Universitaria 1960.

Conard, V.: Mesure de l'assimilation du glucose. Bases théroriques et applications cliniques. Acta gastro-enter. bəlg. 18, 803-845 (1955).

De Bodo, R.C., Altszuler, N.: Insulin hypersensitivity and physiological insulin antagonists. Physiol. Rev. 38, $389-445$ (1958).

- Sinkoff, M. W.: The role of growth hormone in carbohydrate metabolism. Ann. N.Y. Acad. Sci. 57, 23-60 (1953).

Freychet, P., Rosselin, G., Assan, R., Tehobroutsky, G.: Hormones thyroidiennes et metabolisme des glucides. Presse méd. 75, 2261-2266 (1967).

Houssay, B.A. : Acción de la tiroides sobre el metabolismo de los hidratos de carbono y en la diabetes, a) p. 60; b) p. 52. Buenos Aires: El Áteneo Ed. 1945.

Lison, L.: Statistique appliquée à la biologie expérimentale, p. 132. Paris: Gauthier Villars Ed. 1958.

Nelson, N.: A photometric adaptation of the Somogyi method for the determination of glucose. J. biol. Chem. 153, 375-380 (1944).

Orsetti, A., Basseres, J., Macabies, J. : L'insulino-sécrétion chez le chien en état de déséquilibre thyroidien. Ann. Endocr. 31, 5-18 (1970).

Renauld, A., Pinto, J.E.B., Sverdlik, R.C., Foglia, V.G.: Studies on the effect of hyperthyroidism on the insulin response to hyperglycaemia in the dog. Horm. Metab. Res. 3, 247-251 (1971a).

- Studies on the rate of disappearance of exogenous insulin from blood in the dog I). Effect of thyroxine. Acta diabetol. latina 8, 428-436 (1971 b).

Soskin, S., Levine, R., Heller, R. E.: Role of the thyroid in the carbohydrate disturbance which follows hypophysectomy. Amer. J. Physiol. 125, 220-226 (1939).

Stuart Soeldner, J., Slone, D.: Critical variables in the radioimmunoassay of serum insulin using the double antibody technic. Diabetes 14, 771-779 (1965).
Dr. A. Renauld
Dr. J.E.B. Pinto
Dr. R.C. Sverdlik
Dr. V.G. Foglia
Instituto de Fisiología
Facultad de Medicina
Universidad de Buenos Aires
Paraguay $2155,7^{\circ}$ piso
Buenos Aires
Argentina 